\title{
Assessing the sustainability of wheat-based cropping systems using simulation modelling: sustainability $=\mathbf{4 2}$ ?
}

\author{
Carina Moeller $\cdot$ Joachim Sauerborn • \\ Peter de Voil • Ahmad M. Manschadi • \\ Mustafa Pala $\cdot$ Holger Meinke
}

Received: 3 June 2013/Accepted: 1 September 2013/Published online: 5 October 2013

(c) The Author(s) 2013. This article is published with open access at Springerlink.com

\begin{abstract}
Concepts of agricultural sustainability and possible roles of simulation modelling for characterising sustainability were explored by conducting, and reflecting on, a sustainability assessment of rain-fed wheat-based systems in the Middle East and North Africa region. We designed a goal-oriented, model-based framework using the cropping systems model Agricultural Production Systems sIMulator (APSIM). For the assessment, valid (rather than true or false) sustainability goals and indicators were identified for the target system. System-specific vagueness was depicted in sustainability polygons-a system property
\end{abstract}

Handled by: Fusuo Zhang, China Agriculture University, China.

C. Moeller $(\bowtie) \cdot$ H. Meinke

Tasmanian Institute of Agriculture (TIA), University of

Tasmania, Private Bag 98, Hobart, TAS 7001, Australia

e-mail: carina.moeller@utas.edu.au

C. Moeller

Black Mountain Laboratories (73), CSIRO Plant Industry,

Clunies Ross Street, Black Mountain, ACT 2601, Australia

\section{J. Sauerborn}

Institute of Plant Production and Agroecology in the Tropics and Subtropics (380), University of Hohenheim, 70593 Stuttgart, Germany

P. de Voil

Queensland Government, Agriculture, Fisheries, and Forestry, P.O. Box 102, Toowoomba, QLD 4350, Australia

\section{A. M. Manschadi}

Department of Crop Sciences, University of Natural Resources and Life Sciences Vienna, Konrad-Lorenz Str. 24, 3430 Tulln, Austria

M. Pala

International Center for Agricultural Research in the Dry Areas (ICARDA), P.O. Box 114/5055, Beirut, Lebanon derived from highly quantitative data-and denoted using descriptive quantifiers. Diagnostic evaluations of alternative tillage practices demonstrated the utility of the framework to quantify key bio-physical and chemical constraints to sustainability. Here, we argue that sustainability is a vague, emergent system property of often wicked complexity that arises out of more fundamental elements and processes. A 'wicked concept of sustainability' acknowledges the breadth of the human experience of sustainability, which cannot be internalised in a model. To achieve socially desirable sustainability goals, our model-based approach can inform reflective evaluation processes that connect with the needs and values of agricultural decision-makers. Hence, it can help to frame meaningful discussions, from which actions might emerge.

Keywords APSIM - Middle East and North Africa region - Sustainability concepts - Tillage systems . Human values · Vague property · Emergent property . Wicked complexity $\cdot$ Boundary work

\section{Introduction}

Sustainability has long been a popular concept but is hard to quantify. Our study touches on theoretical and practical aspects of sustainability, which we believe are important in order to evaluate and critique the-real or implied-role of simulation techniques for characterising and quantifying agricultural sustainability, and the usefulness of the sustainability concept as a research criterion. It has been frequently proposed that bio-physical systems approaches using simulation techniques are suitable for quantifying agricultural sustainability (Monteith 1996; Hansen 1996; Kropff et al. 2001) in a way that is "literal, system- 
oriented, quantitative, predictive, stochastic and diagnostic" (Hansen 1996, p. 138). Indeed, simulation models have been widely applied to balance, often conflicting, economic and environmental goals (Bergez et al. 2010; Keating et al. 2003, 2010). Examples are the study of Murray-Prior et al. (2005), who used cropping systems simulation to balance trade-offs between increasing profitability while improving soil fertility, and reducing runoff and subsoil drainage in diverse rotations, including wheat and cotton, and that of Muchow and Keating (1998), who identified irrigation guidelines that maximise sucrose yield whilst minimising water losses and groundwater tapping by simulating a sugar cane farming system.

Simulation models are now mainstream research tools in complex systems science (Peck 2004; Bergez et al. 2010). However, their role in assessing and quantifying sustainability beyond trade-off analyses, as discussed above, remains unclear, despite suggestion or claim of the contrary (e.g. Hansen 1996; Kropff et al. 2001). Reasons for this may be conceptual, logical, methodological or practical. Grammatically, the word 'sustainability' is an abstract, uncountable noun. Generic quantifiers such as 'some', 'more' or 'not much' can be used to describe sustainability, but not numbers. Thus, there is incongruity between word properties and the quest for quantification. This adds to the ambiguous nature of sustainability (Cox et al. 1997), which is a hindrance to the development and adoption of a clear assessment framework, although sustainability has long been a popular notion in general terms (e.g. Kane 1999). In the following, we review some of the core issues-many arise from the relations between science and values that are frequently contested and ill-defined (Carrier 2008; Allenby and Sarewitz 2011; Meyer 2011; Benessia et al. 2012).

Notions of agricultural sustainability are broadly centred on "the capacity of agricultural systems to maintain commodity production through time without compromising their structure and function" (e.g. Hansen 1996; Ruttan 1999; Bell and Morse 2000). Most people would have an intuitive understanding of this and agree that agricultural sustainability is something desirable. However, broad agreement on such a public value (Meyer 2011) does not preclude conflict over definitions of sustainability, and how its presence or absence can be assessed. Theoretical concepts of agricultural sustainability have been seen as either goal-describing or system-describing (Thompson 1992). The goal-describing concept specifies a priori how the system ought to be, and entails normative judgements about agricultural practices and their sustainability (Cox et al. 1997; von Wirén-Lehr 2001 refers to it as meansoriented). It has been criticised as being logically flawed (Thompson 1992; Hansen 1996). The argument is that an a priori definition of what 'is sustainable' (in the sense of a prescription) largely eliminates the need for assessment.
However, even a predetermined definition allows evaluation in respect to whether or not the system meets the criteria prescribed by the definition. The system-describing concept seeks to treat sustainability as an objective property intrinsic to a defined system, specifies criteria to predict and explain system behaviour, and is thought to be better suited to form the basis for evidence-based assessments of agricultural sustainability (Hansen 1996; Cox et al. 1997).

In fact, the notion of sustainability itself is strongly influenced by non-empirical knowledge and, hence, any approach to assessing sustainability has normative elements. The question is how and where choices come in and how these choices affect the scientific process. For example, the question that the analyst seeks to explain determines the specification of the system, its external boundaries and internal interactions (Thompson 1992; Kropff et al. 2001). The choice of performance criteria to evaluate system function or dysfunction is closely linked to system specifications (Girardin et al. 1999; Smith et al. 2000; Bouma 2002). As the system specifications and performance criteria depend on the analyst's perspective, their selection is normative, even if it is embedded in sound reasoning (Hollander 1986; Thompson 1992). Thus, the development and adoption of an approach to assessing sustainability can never be purely 'scientific' or 'objective', which stands in stark contrast to the classic self-image of the sciences to proceed under the exclusive rule of logic and facts (Carrier 2008).

Likewise, the development and application of suitable performance criteria (indicators) to monitor change and sustainability has been subject to significant debate (e.g. Girardin et al. 1999; Riley 2001; Nortcliff 2002; Büchs 2003). Indicators have been designed to capture ecological, economic and social dimensions of sustainability for different systems and scales (Meyer et al. 1992; Girardin et al. 1999; Smith et al. 2000; Büchs 2003). The sustainability state of a system is typically assessed by comparing current or predicted indicator states with selected reference states. Reference states have been defined by critical limits, margins of tolerance (Gomez et al. 1996; Arshad and Martin 2002) or by a reference system (Abbona et al. 2007). Yet, there is a lack of generality related to the choice and specification of the reference state (Girardin et al. 1999; Arshad and Martin 2002; Büchs 2003). An example of a conceptual problem is the comparison of an 'unsustainable' reference state with a 'more sustainable' alternative, which would demonstrate some improvement in sustainability, but could hardly be viewed as 'sustainable'. Indicators should condense and convey complex information in a way that assists with making difficult choices. However, indicators also entail the risk of hiding information, especially if several system attributes are 
combined to form composite indicators (Kane 1999; Girardin et al. 1999). Correlations between indicators (e.g. crop yield and the profitability of production) can increase the weight of one aspect of a system relative to the others (Smith et al. 2000; Arshad and Martin 2002), which needs to be considered when interpreting results.

Methodological challenges also originate from the temporal nature of sustainability. Some of these can be addressed using simulation modelling, which allows extrapolation beyond the timeframes typically employed in empirical approaches. However, despite that crop simulation models offer the advantage of capturing temporal variability over the range of the available climatic record (Moeller et al. 2008), value judgement determines how long a system should persist to be rated sustainable. A long time horizon may be important in ecological terms, but could be of little practical value in a rapidly changing economic and policy environment. Similarly, the timing of the assessment can bias the results of the sustainability analysis because system components vary at different scales. For example, the performance criterion 'crop yield' fluctuates at higher frequencies than 'soil organic matter', requiring a different length of assessment to capture the full range of possible, or even likely, outcomes.

Beyond the theoretical views on sustainability discussed above, practical assessment approaches typically entail both normative and objective elements (von Wirén-Lehr 2001). von Wirén-Lehr (2001) referred to the 'hybrid' concept used in practice as "principal goal-oriented concept of sustainability". Respective studies follow a common, five-step strategy involving: (1) the definition of a sustainability paradigm, (2) the formulation of aspired sustainability goals for a specified system, (3) selection of measurable performance criteria, (4) evaluation and (5) advice on sustainable management practices (von WirénLehr 2001).

We adopted such a principal assessment strategy for an ex-post evaluation of a model-based sustainability assessment using a real-world example. This study considers the usefulness of the sustainability concept and assesses the possible roles of simulation modelling for characterising and quantifying aspects of sustainability. Emphasis is placed on the theoretical and practical implications of our findings.

\section{Model-based sustainability assessment framework}

To exemplify a model-based sustainability assessment, we chose a system and environment that is representative of those found in countries of the Middle East and North Africa (MENA) (Cooper et al. 1987; Pala et al. 1999; Ryan et al. 2008). von Wirén-Lehr's (2001) principal assessment strategy guided our analysis of potentially conflicting sustainability goals in wheat-based cropping systems in a semi-arid Mediterranean environment of northwest Syria using the cropping systems model Agricultural Production Systems sIMulator (APSIM; Keating et al. 2003; Moeller et al. 2007).

A brief outline of the steps taken in our assessment is given at the outset here. (1) We reviewed key issues for agricultural sustainability in MENA, and the specific issues in current wheat-based cropping systems. (2) This review informed the formulation of a sustainability paradigm and provided insights into the sustainability goals for guiding change. To address the sustainability issues identified, we then reviewed alternative management strategies and decided on exploring contrasting tillage systems in simulated wheat-chickpea rotations. These were conventional tillage without and with stubble burning and no-tillage. (3) To assess whether the consequences of the alternative tillage systems were to move towards or away from a sustainability state, we evaluated seven sustainability indicators: crop yield, water-use efficiency (WUE) and the gross margin (GM) of both wheat and chickpea, and the amounts of soil organic carbon (OC) across cycles of the rotation. Other indicators could have been chosen which underline our earlier point that the indicator selection can never be comprehensive and, hence, objective. (4) We explored the simulation scenarios of the management practices and used sustainability polygons (ten Brink et al. 1991) to illustrate the sustainability state (as described by the indicators) of an alternative management scenario relative to a reference state. Finally, we discuss the theoretical and practical implications of our findings.

\section{Rationale for the sustainability paradigm}

We formulated the sustainability paradigm for the MENA region as "Sustainable agricultural development contributes to improved food security, increases wealth in rural areas, and maintains agriculturally productive land and water resources".

For over half a century, the MENA region has experienced a decline of per-capita cereal production (Dyson 1999). Production has grown slower than the demand by growing populations. As a consequence, MENA has become the largest food-importing region of the developing world (Pala et al. 1999; Roozitalab 2000). Across the region, the livelihoods of rural populations depend largely on agriculture. Most of the poor live in rural areas, where agricultural workers support their families with an average daily gross domestic product (GDP) of less than 3 US\$ (Rodríguez and Thomas 1998; Roozitalab 2000). Smallholder systems with land holdings of less than 10 ha are common. Technological advances (Pala et al. 1999; Ryan 
et al. 2008) to increase agricultural productivity have aimed at reducing both poverty and the reliance on food imports (Rodríguez 1995; Chaherli et al. 1999).

The most important environmental factor limiting crop productivity in MENA is the highly variable, often deficient, rainfall (Cooper et al. 1987). To reduce climatic risks and boost production, the expansion of irrigation agriculture has been a key strategy (Rodríguez 1995; Rijsberman and Mohammed 2003; Araus 2004). With over $80 \%$ of water resources being used in agriculture, this strategy has led to rapidly diminishing groundwater resources across the region (Araus 2004; Comprehensive Assessment of Water Management in Agriculture 2007). Soil fertility losses due to erosion, soil salinisation, declining soil organic matter and nutrient mining (Pala et al. 1999; Lal 2002) have tightened the dilemma of increasing production in an agroecological region where land and water resources are inherently scarce (Agnew 1995). Thus, to meet the imperative for 'sustainable agricultural development in MENA' (Rodríguez 1995; Chaherli et al. 1999), improved production systems are needed that maintain the resource base and increase the productivity per unit land and water. The intensification of rain-fed (non-irrigated) systems will play a key role for achieving these goals (Cassman 1999).

\section{Rationale for the sustainability goals}

The sustainability goals for wheat-based systems in the MENA region were chosen as "To increase the productivity of rain-fed cropping systems per unit (1) land and (2) water, (3) increase the profitability of production, and (4) maintain or enhance soil fertility".

Across MENA, wheat (Triticum aestivum L. and Triticum turgidum ssp. durum) is the main staple food. Wheatbased systems dominate the zone delineated by the 350-600-mm isohyets. Typical rain-fed wheat-based rotations include food (Cicer arietinum, Lens culinaris, Vicia faba) and feed legumes (Medicago sativa, Vicia sativa) (Cooper et al. 1987; Pala et al. 1999; Ryan et al. 2008). Fields are commonly left fallow over summer, as insufficient moisture prohibits the reliable production of rain-fed summer crops. Long fallows (winter plus summer) have been largely replaced by cropping to increase production through intensified land use (Tutwiler et al. 1997; Pala et al. 2007).

Conventional tillage includes deep ploughing (0.2-0.3$\mathrm{m}$ depth) with a disc or mouldboard plough, followed by seed-bed preparation with tined implements (Pala et al. 1999, 2000). Some farmers may plough up to five times prior to planting. The rational is to obtain a fine, weed-free seed bed. Farmers also manage stubble loads by burning (Tutwiler et al. 1990; López-Bellido 1992). Reasons for stubble burning have been named as to control weeds, pests and diseases, and to facilitate seedbed preparation for the following crop (Pala et al. 2000; Virto et al. 2007). However, these tillage and residue management practices have been shown to degrade soil physical and chemical properties, as indicated by losses in structural stability and soil organic matter (Govaerts et al. 2006; Roldan et al. 2007; Verhulst et al. 2011). Stubble management further includes summer grazing by sheep and goats. Land is rented out to herders following the crop harvest in spring/early summer, which generates additional income for arable farmers in the traditional crop-livestock systems (Tutwiler et al. 1997).

Because of its strategic importance for food security, wheat has become the major irrigated winter crop (Perrier et al. 1991). In Syria, farmers managed to double wheat yields through the use of modern technologies, including irrigation, high-yielding varieties and fertilisers in 10 years since 1980 (Tutwiler et al. 1997). Meanwhile, the productivity of rain-fed wheat-based systems has remained low. Rain-fed wheat produced in the Syrian governorates Homs, Hama, Ghab, Idleb and Aleppo (1988-1997) yielded, on average, $1.1 \mathrm{t} / \mathrm{ha}$ compared to $2.9 \mathrm{t} / \mathrm{ha}$ when irrigation was applied (Ministry of Agriculture and Agrarian Reform 1999). Growth conditions are often characterised by low WUE due to suboptimal agronomic practices, including insufficient weed control and non-aligned nutrient management (Pala et al. 2007; Passioura and Angus 2010). The application of fertiliser is often perceived as too risky because of high rainfall variability (Pala and Rodríguez 1993; Pala et al. 1999). Developing the rain-fed systems would not only contribute to food security but may also reduce the pressure on over-exploited groundwater resources (Varela-Ortega and Sagardoy 2002).

\section{Rationale for an alternative tillage/residue management}

Conservation agricultural practices, including residue retention and no-tillage sowing, have been successfully adopted in other semi-arid regions such as Australia, where they have become a key component of cereal-based systems (Thomas et al. 2007). As part of the sustainability assessment strategy, we reviewed such practices as possible alternatives to the conventional soil and residue management practised in MENA. In semi-arid environments of the Mediterranean region, wheat and barley yields increased with no-tillage compared to conventional tillage under relatively drier conditions as determined by site and/ or season (Lampurlanés et al. 2002; Cantero-Martínez et al. 2003; De Vita et al. 2007). Benefits of conservation agriculture include more efficient crop water use and increased yields through improved soil water infiltration and storage (Bescansa et al. 2006; Verhulst et al. 2011), reduced evaporative losses with residue retention, enhanced soil fertility through higher levels of soil organic matter 
(Mrabet et al. 2001; Roldan et al. 2007), improved timeliness of sowing and reduced fuel consumption through the use of direct seeding (Knowler and Bradshaw 2007). However, farmers also require the system-specific management skills to overcome pitfalls, including increased susceptibility to stubble-borne diseases (Fernandez et al. 2008), reliance on herbicides for weed control and the risk of herbicide-resistant weed populations (D'Emden and Llewellyn 2006), risk of reduced crop $\mathrm{N}$ availability (Angás et al. 2006) and a trade-off between crop residue retention and the need for animal feed (Tutwiler et al. 1997). In other words, conservation agriculture is a knowledge-intensive technology that necessitates in-depth understanding of the possible consequences by farmers. This contrasts with knowledge-embedded technologies (e.g. mineral fertiliser or hybrid seed), which require little, if any, additional knowledge to be applied.

\section{Simulation scenarios}

Current and alternative management strategies were simulated with the cropping systems model APSIM. Model details and a comprehensive description of the simulation scenarios are given in Appendix A. Briefly, the simulations captured the most important features of rain-fed wheat-based systems in the target region, and were conducted for Tel Hadya, northwest Syria, using a typical soil type. The climate at the site is semi-arid Mediterranean (Moeller et al. 2007). Continuous simulations of wheat-chickpea rotations (1979-2005) included three alternative tillage/residue management practices. In the simulated conventional tillage (CT) system, straw residues were removed after harvest and the remaining stubble was incorporated into the soil by deep ploughing. With burn-conventional tillage (BCT), all wheat residues were removed by burning prior to conventional tillage. No-tillage (NT) was simulated with complete residue retention. Fertiliser nitrogen $(\mathrm{N})$ was applied at wheat sowing at five rates ranging from 0 to $100 \mathrm{~kg} \mathrm{~N} / \mathrm{ha}(\mathrm{N} 0, \mathrm{~N} 25$, $\mathrm{N} 50, \mathrm{~N} 75$ and N100). The possible tillage system $\times$ fertiliser rate combinations lead to 15 simulation scenarios.

\section{Sustainability indicators}

In outlining our chosen indicators, we highlight the partial nature of our analysis. Their utility as measures of agroecosystem function has been discussed elsewhere (e.g. Meyer et al. 1992; Smith et al. 2000; Arshad and Martin 2002; Bouma 2002; Murray-Prior et al. 2005; Passioura and Angus 2010). Briefly, the variable 'yield per hectare' integrates all environmental and agronomic aspects of crop production, and is a measure of the efficiency with which resources and agricultural inputs are converted into a single, physical output, namely yield. The agronomic WUE (defined here as the grain yield produced per unit evapotranspiration from sowing until crop maturity) is a measure of the efficiency with which the scarce and variable rainfall is converted into yield. Organic carbon is a key indicator of soil health and function, and integrates agriculturally important soil properties such as aggregate stability, nutrient availability and water retention. The GM measures the degree with which an enterprise activity has covered its variable production costs.

Estimates of costs and prices for calculating the GM of wheat and chickpea production reflect those prior to the current political crisis in Syria (Leenders and Heydemann 2012; Seale 2013). We compiled information on prices and markets in Syria from agricultural statistics (Ministry of Agriculture and Agrarian Reform 2000), farmer interviews (Pape-Christiansen 2001), policy documents (Rodríguez et al. 1999; Wehrheim 2003; Huff 2004; Atiya 2008) and personal communications. It is important to note that the economic environment in Syria has been largely that of a centrally planned economy, despite on-going reforms towards greater market liberalisation (Hopfinger and Boeckler 1996; Huff 2004). For example, farm-gate prices for strategic commodities such as wheat and chickpea have been regulated and do not necessarily reflect prices on the world markets (Huff 2004). Until recently, diesel was highly subsidised and traded at about $40 \%$ below the world fuel price (Atiya 2008).

For the purpose of our study, the GM per hectare was calculated as $\mathrm{GM}=$ gross revenue - variable costs specific to the three alternative tillage systems (Appendix B). One set of costs and returns was used. Thus, the GM varied only with the range and variability of rainfall. In the CT system, the gross revenue was calculated as grain yield plus recovered straw times the grain and straw price, respectively. The calculation was similar for the BCT system, except that all wheat straw was 'burned' and the consequent revenue for straw was zero. With NT, the gross revenue was calculated as grain yield times the grain price. Further details on prices and costs used in the GM calculations are given in Appendix B.

\section{Sustainability criterion and reference system}

We specified the sustainability criterion as "A management system is sustainable if its sustainability state (as described by the sustainability indicators) is similar or enhanced in comparison to a reference state".

To assess whether or not this criterion was met, we illustrated the long-term average values of the sustainability indicators for an alternative management system relative to the values obtained with a reference system in sustainability polygons (ten Brink et al. 1991). In this visual reference-based assessment, the reference (baseline) 
Fig. 1 Sustainability polygons to assess the sustainability of wheat-chickpea rotations at $\mathrm{Tel}$ Hadya (1980-2005): average indicator values (bullet with dash) with a, c, e no-tillage (NT) and b, d, f burnconventional tillage (BCT) relative to the values (set $100 \%$; bullet with dash) obtained with conventional tillage $(\mathrm{CT})$ and the application of $50 \mathrm{~kg} \mathrm{~N} / \mathrm{ha}$ to wheat. In the NT and BCT systems, the amounts of fertiliser $\mathrm{N}$ applied to wheat were $\mathbf{a}, \mathbf{b} 0$ ( $\mathrm{NO}), \mathbf{c}$, d 50 (N50) and e, f 100 (N100) $\mathrm{kg} \mathrm{N} / \mathrm{ha}$. Indicators: wheat (W) and chickpea (CP) yield, water-use efficiency (WUE), gross margin (GM) and soil organic carbon in $0-0.3-\mathrm{m}$ depth (OC)

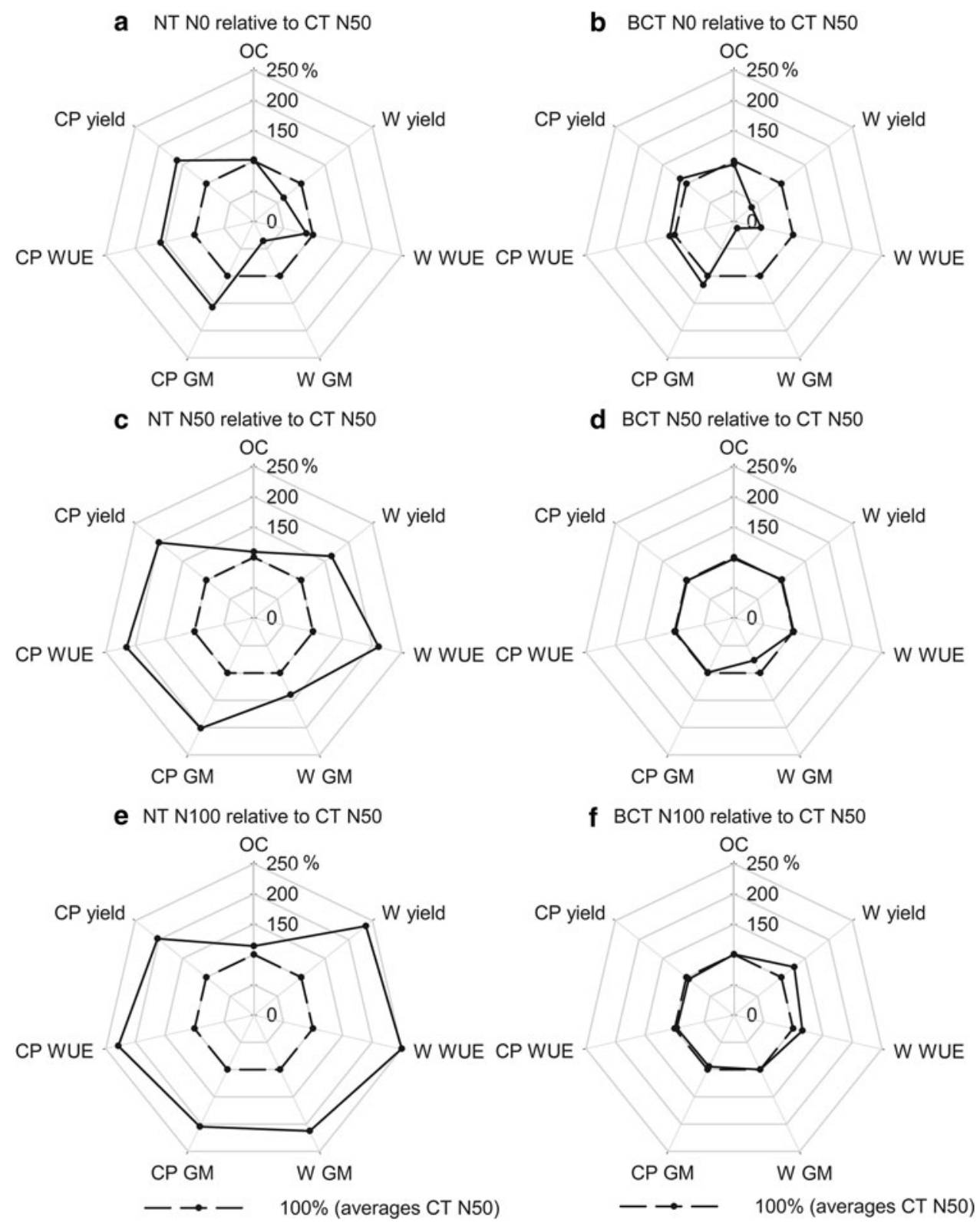

system was a wheat-chickpea rotation subjected to CT in which wheat received fertiliser $\mathrm{N}$ at a rate $50 \mathrm{~kg} \mathrm{~N} / \mathrm{ha}$ of at sowing, and represents agronomic practices that are typical for the study region (Pala et al. 1999). For the purpose of our study, we chose to illustrate the long-term average of all indicators. However, different aggregations for different types of indicators could have been chosen (e.g. start and endpoints for data showing a trend or running averages to illustrate state changes over time).

\section{Assessment results}

The sustainability polygons (Fig. 1) illustrate the results simulated for an alternative management scenario relative to those obtained in a reference scenario, and visualise whether the consequences of the simulated management practices were to move towards or away from the sustainability goals. This integrated assessment showed that NT addressed all sustainability goals by improving yield, the efficiency with which scarce rainfall was converted into yield, profitability and soil quality in the rain-fed wheatbased system.

Specifically, NT performed better than CT and BCT in all sustainability indicators, except when no fertiliser $\mathrm{N}$ was applied to wheat (Fig. 1; Table 1). Enhanced sustainability with NT, was first of all, a consequence of soil water conservation with the residue mulch. Residue retention also improved levels of $\mathrm{OC}$, except when no fertiliser $\mathrm{N}$ was applied. The minimum $\mathrm{N}$ rate required for the NT system 
Table 1 Average grain yield, water-use efficiency (WUE), gross margin (GM), gross revenue (GR) from grain and straw sales, and soil organic carbon (OC) in wheat-chickpea rotations (1980-2005) simulated with conventional tillage (CT), burn-conventional tillage (BCT) and no-tillage (NT)

\begin{tabular}{|c|c|c|c|c|c|c|c|c|c|}
\hline & \multicolumn{3}{|l|}{ Wheat } & \multicolumn{3}{|l|}{ Chickpea } & \multicolumn{3}{|l|}{ Rotation } \\
\hline & CT & BCT & NT & CT & BCT & NT & CT & BCT & NT \\
\hline Yield (t/ha) & $1.70(0.93)$ & $1.73(0.94)$ & $2.80(0.75)$ & $0.83(0.36)$ & $0.82(0.37)$ & $1.66(0.37)$ & & & \\
\hline WUE $(\mathrm{kg} / \mathrm{ha} / \mathrm{mm})$ & $5.67(2.66)$ & $5.72(2.69)$ & $11.95(2.93)$ & $2.79(0.77)$ & $2.76(0.78)$ & $6.00(1.07)$ & & & \\
\hline GM (€/ha) & 309 (204) & 237 (183) & $431(146)$ & 230 (119) & $227(121)$ & $463(119)$ & & & \\
\hline GR grain $(€ /$ ha $)$ & $370(202)$ & 375 (203) & $607(162)$ & 295 (128) & $292(131)$ & $589(132)$ & & & \\
\hline GR straw $(€ /$ ha $)$ & $77(24)$ & 0 & 0 & $13(4)$ & $13(4)$ & 0 & & & \\
\hline $\mathrm{OC}(\mathrm{t} / \mathrm{ha})^{\mathrm{a}}$ & & & & & & & $20.00(0.63)$ & $19.24(0.49)$ & $20.70(1.52)$ \\
\hline
\end{tabular}

Results are given for an $\mathrm{N}$ fertiliser rate of $50 \mathrm{~kg} \mathrm{~N} / \mathrm{ha}$ applied at wheat sowing. Results for CT are those of the reference system (details are given in text). Standard deviations are given in parentheses

${ }^{a}$ Average amount of soil organic carbon in $0-0.3-\mathrm{m}$ soil depth on 1 November (start of the season)

to outperform the reference system was N25 (not shown). When no fertiliser $\mathrm{N}$ was applied, $\mathrm{N}$ limitations reduced wheat yield, GM and WUE (but not OC), and, ultimately, the sustainability of all tillage systems. However, chickpea benefited somewhat from residual soil moisture left from a preceding N-limited wheat crop, which explained why the chickpea indicators yield, WUE and GM performed slightly better as in the reference system (CT with N50). The modelling showed that burning wheat stubble in the BCT system constrained sustainability by reducing revenue (consequently GM) at $\mathrm{N}$ rates of $\mathrm{N} 0, \mathrm{~N} 25$ and $\mathrm{N} 50$ (Fig. 1d). Revenue was lost primarily by missing out on the productivity benefits from soil water conservation and by not selling straw as animal feed (Table 1). Application of high $\mathrm{N}$ rates (N75 and $\mathrm{N} 100)$ compensated for revenue losses incurred by burning wheat stubble (Fig. 1f). Detailed diagnostic evaluations of causes and effects, and variability and trend of the indicator values complemented the integrated assessment using sustainability polygons. These are presented in Appendix C.

\section{Discussion}

We explored aspects of sustainability by modelling a particular system consisting of a manageable number of entities that are arguably well understood and described structurally and mechanistically in APSIM. The sustainability polygons enabled an integrative view on sustainability by collapsing the range of quantitative data (Appendix C) into simple graphs visualising numerous responses (Fig. 1). Correlations between indicators (e.g. yield and gross margin) are revealed in the sustainability polygons. This is an advantage over composite indicators, which can be biased by hidden correlations. The polygons allow an instantaneous judgement of the system's sustainability: 'better', 'neutral' or 'worse'. These descriptors are neither quantitative nor exact. In fact, the assessment results are deliberately qualitative and vague; there can be different degrees of 'better', influenced by norms and values of the analyst. However, this qualitative property is derived from highly quantitative simulation data. The demonstration of vagueness echoes the discourse on contested values embedded in the concept of sustainability (e.g. Bell and Morse 2000), and is a strength of the approach because the human experience of 'what constitutes sustainability' cannot be fully internalised in, and represented by, a model. In contrast, an exact measure of sustainability would be paradoxical, and unlikely to be meaningful for practical decision-making; in fact, it is illogical to answer a fuzzy question ("what constitutes sustainability?') with a precise number. Or, by paraphrasing Adams (1979): "the answer to [sustainability,] life, the universe and everything equals 42 ", which is a very precise but an utterly meaningless answer.

Based on our analysis, we argue that vagueness is a core property of sustainability, and that system-specific vagueness can be denoted using descriptive quantifiers (e.g. 'greater'). However, the detailed, diagnostic evaluations (Appendix C) also demonstrate the power of bio-physical modelling to quantify, predict and diagnose constraints to sustainability that are important for wheat-based systems in the semi-arid study environment, and identify management practices that can address defined sustainability goals related to land and water productivity, profitability and soil fertility (Appendix C). Key bio-physical (crop growth and water) and chemical ( $\mathrm{N}$ and $\mathrm{C}$ ) processes can be numerically described in time (by simulating responses across seasons) and space (by simulating responses for contrasting soils; e.g. Moeller et al. 2009) using models such as APSIM. Thus, individual system components can be quantified and predicted, while there is vagueness at a higher level of integration in our framework. It follows that sustainability is better described as an 'emergent property', 
which "arise(s) out of more fundamental entities and yet (is) novel and irreducible with respect to them" (O'Connor and Wong 2012).

It is valid to argue that the bio-physical modelling presented here is a form of 'organised simplicity' inapt to truly capture sustainability as, for example, human choices and decision-making are not explicitly included in the modelling. Intimately linked to such valid critique of the approach and framework are the questions of which system components to choose, the specifications of system boundaries, the context in hierarchy and the criteria for judging success or failure. However, to elicit such critique and concrete questions is precisely the purpose of the approach. Indeed, it is a characteristic of research in complex systems that, as more entities and processes are considered, uncertainty increases and predictability decreases. Thus, there is a clear need to specify and define the target system for analytical reasons (Hansen 1996; Monteith 1996; Peck 2004). Implicit to this is a natural sciences' view of scientific rigour and complexity we can describe and, hence, grasp (Allenby and Sarewitz 2011). In this context, the elements of sustainability as characterised here by the model manifest themselves as deterministic knowledge, whereby all outcomes and the probabilities of these outcomes (e.g. Fig. 5 in Appendix C) are 'known'. In reality, however, systems are interrelated at various scales, uncertainty confines predictability and the human experience of sustainability extends beyond the in silico environment. Hence, it is exactly this property that constitutes the real value of the framework and our analysis: policymakers and practitioners will have to accept that fuzzy answers-as exemplified in the sustainability polygons (e.g. 'greater' or 'not much' sustainability)—may be the best expression of expertise; scientists will have to learn that the identification of the fuzzy space between deterministic knowledge, perception and ignorance may be the sign of real competence (Walker and Marchau 2003).

Based on our evaluation, we argue that the separation of the goal-describing and system-describing concepts of sustainability (as reviewed in the Introduction) is, in its core, artificial and practically irrelevant. Intrinsic to any sustainability concept and subsequent assessment must be some a priori understanding of success or failure of a predefined system. It is the very process of specification and definition of a target system, as detailed here, which demonstrates that sustainability can never be an 'objective system property' (Hansen 1996, p. 134). In statistics, objective properties are mean, median, standard deviation, among others. Simulation models are based on objective bio-physical principals (Bergez et al. 2010; Keating et al. 2003). In contrast, the criteria for evaluating success or failure in the sustainability of a defined agricultural system (e.g. wheat-based systems in MENA) are a matter of choice and the consequence of a societal discourse. Useful sustainability indicators are valid, rather than true or false.

Change towards sustainability is arguably the leitmotif in any sustainability assessment, with the endpoint typically being the provision of advice to decision-makers and the presentation of findings as a fait accompli (as described in the review by von Wirén-Lehr 2001, but not included here). Implicit to this approach is a very specific, linear epistemological model that often fails to deliver desirable changes because of the disconnect between the generation of new knowledge, and the needs and values that inform the sustainability goals of individual decision-makers in the farming community. An example from developing countries is the enthusiastic promotion of conservation agricultural practices for sustainability by researchers (e.g. Kassam et al. 2012; Lal 2000, and some literature reviewed as part of our assessment strategy), and the reluctance or refusal of many farmers to adopt this knowledge-intensive technology, which highlights that important agro-ecological and socio-economic constraints and complexities have not been considered in the research (see Giller et al. 2009 for a review on the suitability of conservation agriculture in small-holder systems in Africa).

So, the question arises as how to connect the in silico knowledge generated by our model-based assessment framework with the needs, values and the consequent sustainability goals of individual decision-makers. Firstly, sustainability should be viewed as a process rather than an endpoint of assessment. Secondly, viewing sustainability as a process implies a cyclic epistemological model (in contrast to the linear knowledge model discussed above), which evolves through time, as do the needs and sustainability goals of individuals (see also the 'adaptation cycle' described by Meinke et al. 2009). Research that straddles the generation of new knowledge and the various perceptions of what constitutes reliable and relevant knowledge in the face of complex and changing political, economic, social and bio-physical environments has been described as "boundary work" (Guston 2001; Clark et al. 2011) or "participatory action research" (Carberry et al. 2002; McCown 2001, 2002). Boundary work using bio-physical modelling has been applied successfully in Australia, where it involved iterative learning cycles in which the participating researchers, policy-makers and farmers (re-)designed and (re-)evaluated simulation scenarios as informed by practical experience and empirical observations (Meinke et al. 2001; Kokic et al. 2007; Nelson et al. 2007, 2010a, b). Such participatory, reflective modelling can cater for the various perceptions of sustainability (other than the single perception put forward in this study), as well as changes in perceptions throughout the participatory learning process.

Conflicts and contradictions in respect to "what constitutes a sustainable social, environmental, and economic 
outcome" that extends beyond the modelled system must be anticipated. In our analysis, the use of $\mathrm{N}$ fertiliser improved the values of all sustainability indicators in systems without stubble burning (Fig. 1). Nitrogen fertiliser is a means to increase productivity (Appendix C) and therefore contributes to food security in MENA (Pala and Rodríguez 1993; Rodríguez 1995; Tutwiler et al. 1997; Ryan et al. 2008). However, $\mathrm{N}$ fertiliser is also a nonrenewable, emission-intensive agricultural input, and an environmental pollutant (Erisman et al. 2013). Similarly, there are sustainability trade-offs associated with alternative choices and priorities in conservation agriculture. For example, recent research conducted in Syria and Iraq instigated farmers' interest in affordable, locally made notillage seeders-a success for researchers who had identified potential benefits of the technology for the region. Farmers responded to opportunities related to reduced fuel consumption (environmental and socio-economic benefits) and labour input (socio-economic benefit for a farmer and socio-economic loss for a farm worker) but remained sceptical about the long-term benefits of residue retention because residues are a feed resource for both arable farmers and livestock herders (Tutwiler et al. 1997; Jalili et al. 2011; Kassam et al. 2011). The socio-economic fabric of the traditional crop-livestock systems (Tutwiler et al. 1997) is likely to be affected in some way by changes in residue use. Embedded in a boundary approach, our model-based framework can assist exploring, and reflecting on, sustainable solutions for such difficult, applied problems that influence the triple bottom line. However, there is limited knowledge about the effectiveness of boundary work using bio-physical modelling in small-scale farming systems of MENA, although some successful applications have been reported from developing countries in other regions (Whitbread et al. 2010; Clark et al. 2011).

In formulating our sustainability paradigm, we acknowledged that 'what constitutes sustainability' is scale-dependent. Constraints to sustainability related to, for example, resources' endowment, population growth and political change (e.g. Agnew 1995; Rodríguez 1995; Chaherli et al. 1999; Araus 2004; Bank and Becker 2004; Leenders and Heydemann 2012; Seale 2013) are outside of the system being modelled but impact on sustainability at the farm/field scale in profound ways that are often surprising and unpredictable. For example, the disruption of the largely statecontrolled economy (Hopfinger and Boeckler 1996; Bank and Becker 2004; Huff 2004) in consort with the current political crisis in Syria (which was unforeseeable just a few years ago) means that previously highly subsidised diesel prices (Appendix B; Table 3) are now up to seven-fold higher compared to 2008 (Atiya 2008). Much of the diesel is traded via increasingly important black markets (personal communications). With diesel being a critical agricultural input, farmers would have reviewed their priorities and choices (e.g. plough more shallow/less frequently) and attempt to adapt to this and other novel circumstances over which they have no control. This example demonstrates that sustainability can be an issue of wicked complexity in which "a system's makeup and dynamics are dominated by differing (or even antagonistic) human values and by deep uncertainty not only about the future but even about knowing what is actually going on in the present. Any solution to a wicked problem should be expected to create unanticipated but equally difficult new problems [...]." (Allenby and Sarewitz 2011, p. 109). The consequent sustainability concept would be a 'wicked concept of sustainability', which acknowledges that there is no universally excepted answer to the question of sustainability. This may be viewed as a rather sobering conclusion. And, yet, while there is no finite resolution, socially desirable outcomes can emerge from a commitment to confronting and working with the perceptions and contested values embedded in the concept of sustainability.

\section{Conclusions}

We outlined that vagueness is a core property of sustainability, and that system-specific vagueness can be denoted using descriptive quantifiers. The model can be used to assess trade-offs and constraints to sustainability in ways that would be impossible in vivo. It is a quantitative, predictive and diagnostic tool for characterising important, but partial aspects of sustainability in wheat-based systems of the Middle East and North Africa (MENA). We stress that inherent values and individual choices cannot be fully internalised in a model. Hence, sole reliance on a model (any model) in sustainability assessments would be a rather technocratic confinement attempting to understand sustainability outside of the wider societal discourse and context. Yet, the model-based assessment framework has value when it serves as a powerful, exploratory core element in conversations with diverse stakeholders. It is a research approach that embraces and connects clearly with the needs and values of decision-makers in the farming community. In light of our analysis, we conclude that sustainability is as a vague, emergent system property of often wicked complexity. This property applies within the realm of methodologically grounded norms, values and constraints that are inherent to any assessment strategy. Rather than being the endpoint of an assessment, a 'wicked concept of sustainability' may guide a research process within an adaptive framework that integrates thinking, traditions and practices of both the natural and social sciences.

Acknowledgements The first author is indebted to the staff at ICARDA, Syria, for their support and generosity, particularly Atef 
Haddad, Dolly Mousally, Um Muhana, Turkiye, Sumaya, Abu Nadim and Abdul Karim. Peace. The study was funded by the German Academic Exchange Service (DAAD), Eiselen Foundation Ulm, and the Ministry of Science, Research and the Arts Baden-Württemberg, Germany.

Open Access This article is distributed under the terms of the Creative Commons Attribution License which permits any use, distribution, and reproduction in any medium, provided the original author(s) and the source are credited.

\section{Appendix A: Model simulations}

Model description, parameterisation and testing

A configuration of APSIM (version 4.2) was applied, which included the WHEAT (version 3.1) and CHICKPEA crop modules, and the SOILWAT2, SOILN2 and SurfaceOM modules (Moeller et al. 2007). APSIM simulates, on a daily basis, phenological development, leaf area growth, biomass accumulation, grain yield, nitrogen (N) and crop water uptake. Simulations are performed assuming healthy crop stands free from weeds, pests and diseases. Modules for soil water (SOILWAT2), nitrogen (N) and carbon (C) (SOILN2), and processes related to surface residue dynamics (SurfaceOM) operate for a onedimensional, layered soil profile. SOILWAT2 is a cascading soil water balance model. Water-holding characteristics are specified in terms of the saturated water content (SAT), the drained upper limit (DUL) and the lower limit (LL15) of plant available soil water, and the air dry (AD) soil water content.

APSIM has been extensively tested against data from experimental studies, which demonstrated that the model is generic and mature enough to simulate crop productivity and changes in the soil resource in diverse production situations and environments including different soil types and crops (Meinke et al. 1997; Probert et al. 1998a, b; Robertson et al. 2002; Moeller et al. 2007; Mohanty et al. 2012), N fertiliser treatments (Meinke et al. 1997; Probert et al. 1998a), water regimes (Probert et al. 1998a, b) and tillage/residue management systems (Probert et al. 1998a, b; Luo et al. 2011). The testing of model performance for the conditions at Tel Hadya has been described in detail by Möller (2004) and Moeller et al. (2007), which showed that APSIM is suitable for simulating wheat-based systems in the study environment. Briefly, APSIM was parameterised to simulate biomass production, yield, crop water and $\mathrm{N}$ use, and the soil organic matter dynamics as observed in wheat/chickpea systems. The model satisfactorily simulated the yield, water and $\mathrm{N}$ use of wheat and chickpea crops grown under different $\mathrm{N}$ and/or water supply levels as observed during the 1998/99 and 1999/00 seasons. Long-term soil water dynamics in wheat-fallow and wheat-chickpea rotations (1987-1998) were well simulated when the soil water content in 0-0.45-m soil depth was set to 'air dry' at the end of the growing season each year. This was necessary to account for evaporation from deep and wide cracks in the montmorillonitic clay soil, which is not explicitly simulated in APSIM. The model satisfactorily simulated the amounts of $\mathrm{NO}_{3}-\mathrm{N}$ in the soil, while it underestimated $\mathrm{NH}_{4}-\mathrm{N}$. APSIM was capable of simulating long-term trends (1985-1998) in soil organic matter in wheat-fallow and wheat-chickpea rotations at Tel Hadya, as reported in the literature (Möller 2004).

Simulation scenarios

The simulation scenarios captured typical features of wheatbased systems in the study environment. Simulations were conducted for a montmorillonitic, cracking clay soil at Tel Hadya, northwest Syria $\left(36^{\circ} 01^{\prime} \mathrm{N}, 36^{\circ} 56^{\prime} \mathrm{E} ; 284 \mathrm{~m}\right.$ above sea level). The site is located in the medium rainfall zone dominated by wheat-based systems. The climate is semi-arid Mediterranean, with an average annual rainfall of $348 \mathrm{~mm}$ and an average annual temperature of $17.7^{\circ} \mathrm{C}$. Over $85 \%$ of the rainfall occurs during the winter growing season (November to May). A typical soil type with a plant available water capacity of $256 \mathrm{~mm}$ in 1.5-m depth was simulated (Fig. 2).

The wheat-chickpea rotations were simulated for the full length of the available historic weather record (1979-2005) using daily maximum and minimum temperatures, solar radiation and rainfall as model inputs. Simulations started with the wheat cycle of the rotation on 30 October 1979 . The timing of wheat sowing depended on the opening rains of the season. The sowing window for wheat was 1-25 November. The sowing of wheat (similar to cv. Cham3) was simulated when the cumulative rainfall over 5 days was $20 \mathrm{~mm}$ or the water content in $0-0.15-\mathrm{m}$ depth exceeded $25 \%$ of the plant available water (PAW). If a sowing opportunity did not occur by 25 November, wheat was sown on 26 November. The sowing depth was $0.05 \mathrm{~m}$, and the plant density was 300 plants $/ \mathrm{m}^{2}$. Chickpea (similar to cv. Gharb2) was sown between 1 and 20 December when the cumulative rainfall over 5 days was $20 \mathrm{~mm}$ or the water content in $0-0.15 \mathrm{~m}$ depth exceeded $25 \%$ of the PAW. If a sowing opportunity did not occur before 20 December, sowing was simulated on 21 December. Chickpea was sown at 0.05-m depth and a plant density of 50 plants $/ \mathrm{m}^{2}$. Five rates of fertiliser $\mathrm{N}$ were applied at wheat sowing (N0, N25, N50, N75 and N100).

For the sustainability analysis, we contrasted current conventional tillage systems (CT and BCT) with an alternative management using residue retention (NT), as specified in Table 2. In the simulated conventional tillage systems, primary tillage to $0.25-\mathrm{m}$ depth occurred on 15 October and secondary tillage to $0.1-\mathrm{m}$ depth on the day of sowing. 


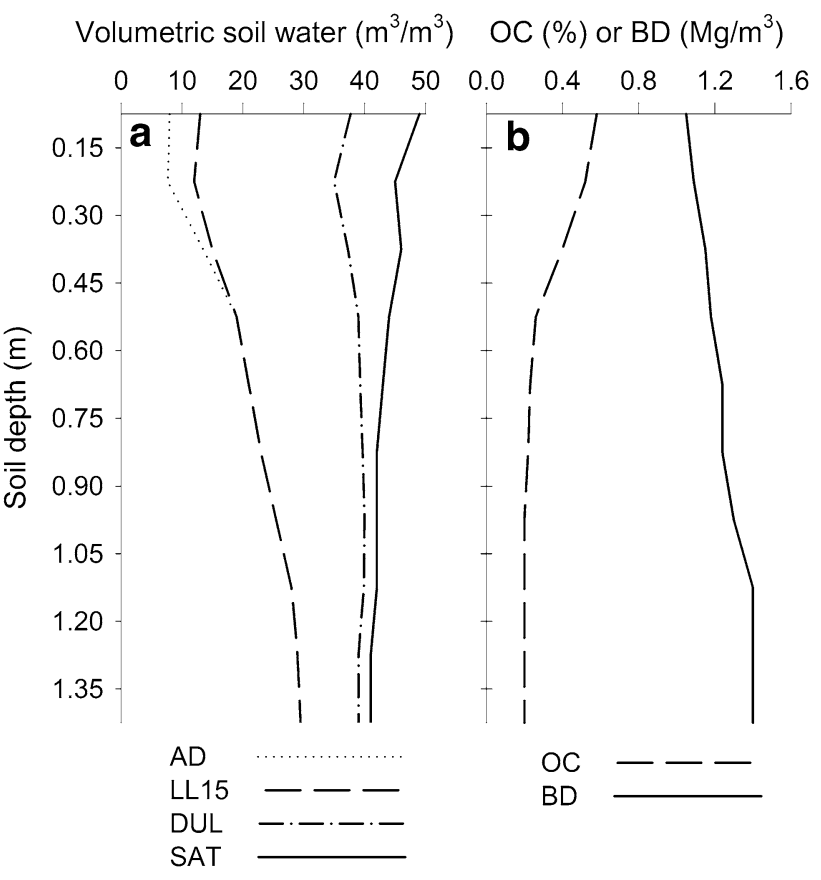

Fig. 2 Characteristics of the clay soil at Tel Hadya. a Volumetric soil water content at near saturation (SAT), drained upper limit (DUL), the lower limit of plant extractable soil water (LL15) and air dry soil water content (AD). b Percentage soil organic carbon (OC) and bulk density (BD)

Initial soil conditions for 30 October 1979 were as described by Moeller et al. (2007). The amount of plant available soil water was $39 \mathrm{~mm}$ and soil mineral $\mathrm{N}$ was $120 \mathrm{~kg} / \mathrm{ha}$ in $0-1.5-\mathrm{m}$ depth. The surface residue pool was initialised at 1 t/ha wheat straw. The percentage soil organic carbon was $0.58 \%$ in $0-0.15-\mathrm{m}$ soil depth (Fig. 2), representing $9.18 \mathrm{t} / \mathrm{ha}$ organic carbon (OC) or $1 \%$ soil organic matter. After each cycle of the rotation, the soil water content was set to 'air dry' in 0-0.3-m depth on 19 June, and, subsequently, in 0-0.45-m depth on 4 July, which was necessary to account for soil evaporation from soil cracks, which is not explicitly simulated in APSIM (Moeller et al. 2007).

Because the starting conditions (i.e. amount of surface residues, soil mineral $\mathrm{N}$ and soil water) were the same in all simulation scenarios, we discounted the start-up season

Table 2 Specifications of the residue management in three simulated tillage systems

\begin{tabular}{|c|c|c|c|c|}
\hline \multirow[t]{2}{*}{ Tillage system } & \multicolumn{2}{|c|}{$\begin{array}{l}\text { Residues removed } \\
\text { at harvest of: }\end{array}$} & \multicolumn{2}{|c|}{$\begin{array}{l}\text { Residues incorporated } \\
\text { during: }\end{array}$} \\
\hline & $\begin{array}{l}\text { Wheat } \\
(\%)\end{array}$ & $\begin{array}{l}\text { Chickpea } \\
(\%)\end{array}$ & $\begin{array}{l}\text { Primary } \\
\text { tillage }(\%)\end{array}$ & $\begin{array}{l}\text { Secondary } \\
\text { tillage }(\%)\end{array}$ \\
\hline Conventional (CT) & 75 & 50 & 90 & 10 \\
\hline $\begin{array}{l}\text { Burn-conventional } \\
\text { (BCT) }\end{array}$ & 100 & 50 & 90 & 10 \\
\hline No-tillage (NT) & 0 & 0 & 0 & 0 \\
\hline
\end{tabular}

(1979-1980) in subsequent analyses. Thus, there were 12 years of wheat data and 13 years of chickpea data in each scenario.

\section{Appendix B: Gross margin calculations}

We assumed the use of advanced technology and that all machinery, except a combine for harvesting, was owned by

Table 3 Summary of variable costs used in the calculation of the gross margin for one hectare of wheat and chickpea

\begin{tabular}{|c|c|c|}
\hline Item & $€ /$ ha & Comments/specifications \\
\hline \multicolumn{3}{|l|}{ Agricultural inputs ${ }^{\mathrm{a}}$} \\
\hline $\begin{array}{l}\text { Wheat seeds incl. } \\
\text { treatment }(160 \mathrm{~kg} / \mathrm{ha})\end{array}$ & 65 & Wheat only \\
\hline $\begin{array}{l}\text { Chickpea seeds incl. } \\
\text { treatment }(80 \mathrm{~kg} / \mathrm{ha})\end{array}$ & 19 & Chickpea only \\
\hline $\begin{array}{l}\text { Phosphorus fertiliser } \\
(15 \mathrm{kgP} / \mathrm{ha} ; 23 \% \mathrm{P})\end{array}$ & 4 & \\
\hline $\begin{array}{l}\text { Nitrogen fertiliser } \\
(50 \mathrm{~kg} \mathrm{~N} / \mathrm{ha} ; 46 \% \mathrm{~N})\end{array}$ & 13 & $\begin{array}{l}\text { Wheat only; } 50 \mathrm{~kg} \mathrm{~N} / \mathrm{ha} \text { were } \\
\text { applied in the reference scenario }\end{array}$ \\
\hline $\begin{array}{l}\text { Herbicide, single } \\
\text { application }\end{array}$ & 5 & $\begin{array}{l}\text { Conventional tillage: one } \\
\text { application; no-tillage: four } \\
\text { applications }\end{array}$ \\
\hline $\begin{array}{l}\text { Fungicide, single } \\
\text { application }\end{array}$ & 2 & Applied once \\
\hline $\begin{array}{l}\text { Insecticide, single } \\
\text { application }\end{array}$ & 7 & Applied once in chickpea only \\
\hline \multicolumn{3}{|c|}{ Operation of owned machinery (diesel cost only $)^{b}$} \\
\hline Mouldboard plough & 3.8 & $\begin{array}{l}\text { Conventional tillage only; working } \\
\text { width: } 0.7 \mathrm{~m} \text {; working resistance: } \\
\text { heavy }\end{array}$ \\
\hline $\begin{array}{l}\text { Combined harrowing } \\
\text { and sowing }\end{array}$ & 1.2 & $\begin{array}{l}\text { Conventional tillage only; working } \\
\text { width: } 2 \mathrm{~m} \text {; working resistance: } \\
\text { light }\end{array}$ \\
\hline Direct seeding & 0.6 & $\begin{array}{l}\text { No-tillage only; working width: } \\
3 \text { m; working resistance: light }\end{array}$ \\
\hline Fertilisation $(\mathrm{N}$ and $\mathrm{P})$ & 2.1 & $\begin{array}{l}\text { Working width: } 12 \mathrm{~m} \text {; single } \\
\text { application }\end{array}$ \\
\hline $\begin{array}{l}\text { Spraying (herbicide, } \\
\text { fungicide and } \\
\text { insecticide) }\end{array}$ & 1.2 & $\begin{array}{l}\text { Working width: } 12 \mathrm{~m} \text {; single } \\
\text { application }\end{array}$ \\
\hline
\end{tabular}

Straw removal

0.3 Conventional tillage only, except when wheat stubble was burned; working width: $5.75 \mathrm{~m}$; trailer capacity: $1.4 \mathrm{t}$

Hired machinery and labour ${ }^{\mathrm{c}}$

Combine harvester $\quad 10 \%$ of gross revenue from grain sales

If not specifically mentioned, costs applied in the production of both wheat and chickpea under conventional and no-tillage

a,c Based on budgeting information from the Ministry of Agriculture and Agrarian Reform (2000)

b The diesel consumption per operation was based on technical information provided by Kuratorium für Technik und Bauwesen in der Landwirtschaft (2009). A tractor with a 56-kW take-off power was assumed. The distance to the field was $1 \mathrm{~km}$ 
the farmer. In all our calculations, the Syrian Pound was converted to $€$ at $70 \mathrm{SYP}=1 €($ OANDA 2009). The price of 1 tonne of wheat grain was $€ 217$ and the price of 1 tonne of chickpea grain was $€ 354$ (Ministry of Agriculture and Agrarian Reform 2000). The price of 1 tonne of wheat and chickpea straw was $€ 29$ and $€ 14$, respectively (Pape-Christiansen 2001). Variable costs included the costs of machinery use (diesel only), seed, pesticide and fertiliser (Table 3). The cost of 11 of diesel was $€ 0.11$ (Atiya 2008). The harvest costs were $10 \%$ of the gross revenue from grain sales (Ministry of Agriculture and Agrarian Reform 2000).

\section{Appendix C: Results of diagnostic evaluations}

Enhanced sustainability in the NT system was primarily related to soil water conservation with the residue mulch (Fig. 3). In the NT system, the average amount of surface residues on 1 November (start of season) was $3.9 \mathrm{t} / \mathrm{ha}$ with $\mathrm{N} 0$, increasing to $10.8 \mathrm{t} / \mathrm{ha}$ with N100. Residue removal
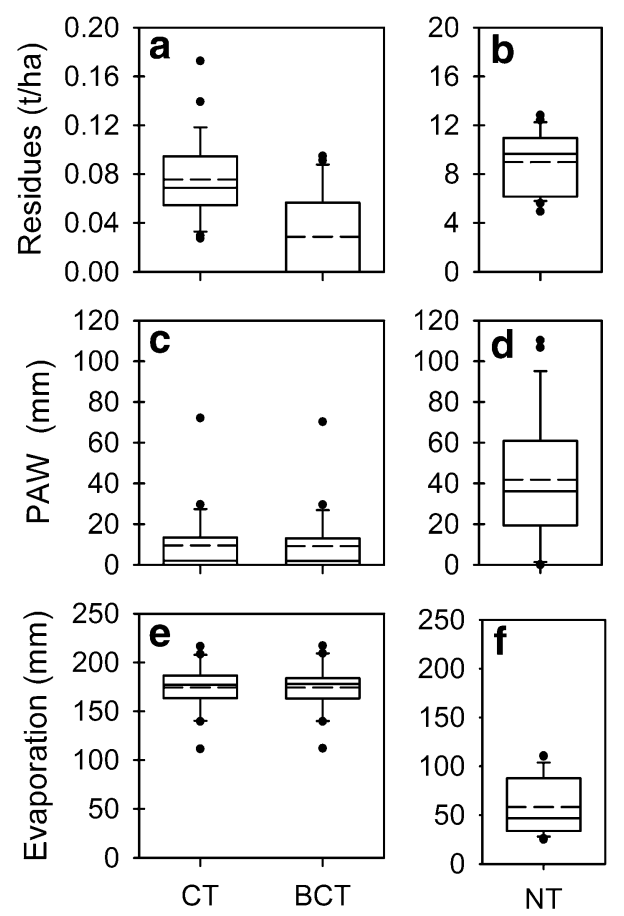

Fig. 3 Surface residues $(\mathbf{a}, \mathbf{b})$ and plant available soil water (PAW) in $0-1.5-\mathrm{m}$ depth $(\mathbf{c}, \mathbf{d})$ on 1 November, and cumulative soil evaporation from sowing until crop harvest $(\mathbf{e}, \mathbf{f})$ in wheat-chickpea rotations simulated for Tel Hadya (1980-2005): a, c, e conventional tillage (CT) and conventional tillage with stubble burning after wheat (BCT); b, d, f no-tillage (NT). In all tillage systems, fertiliser $\mathrm{N}$ was applied to wheat only at a rate of $50 \mathrm{~kg} \mathrm{~N} / \mathrm{ha}$. The boxes mark the lower and upper quartiles, the solid and dashed lines show the median and mean, respectively, and the whiskers represent the 10th and 90th percentiles. The results for CT represent those of the reference scenario and primary tillage in the $\mathrm{CT}$ system decreased these average amounts to $0.05 \mathrm{t} / \mathrm{ha}$ with $\mathrm{N} 0$ and $0.08 \mathrm{t} / \mathrm{ha}$ with N100. Stubble burning (BCT) further decreased the residue amounts (Fig. 3a). As a consequence of residue retention in the NT system, soil evaporation $\left(E_{\mathrm{s}}\right)$ during the cropping phase of the rotation was lower, and the PAW stored in the soil profile $(0-1.5-\mathrm{m}$ depth) at the start of the season was higher compared to CT and BCT. The average in-crop $E_{\mathrm{s}}$ in the NT system was $134 \mathrm{~mm}$ with N0, decreasing to $43 \mathrm{~mm}$ with N100 compared to $184 \mathrm{~mm}$ with N0 and $170 \mathrm{~mm}$ with N100 in both the CT and BCT systems. With NT, the average amounts of PAW stored in the profile were similar across $\mathrm{N}$ treatments and ranged between 35 and $40 \mathrm{~mm}$ at the start of the season. In contrast, these amounts of PAW averaged $17 \mathrm{~mm}$ with $\mathrm{N} 0$, decreasing to $6 \mathrm{~mm}$ with N100 in the CT and BCT systems.

The variability of wheat yield (Fig. 4a, b) and WUE (Fig. 4e, f) increased with increasing amounts of fertiliser $\mathrm{N}$, indicating that growth was limited primarily by $\mathrm{N}$ in relatively wetter seasons, while water was limiting in drier seasons. This increase in variability was greater with CT and BCT compared to NT. The N rate required to maximise the average wheat yield and WUE was highest with NT (Fig. 4b, f), but similar with CT and BCT (results not shown).

For chickpea, the variability of yield (Fig. 4c, d) and WUE (Fig. 4g, h) was similar in all treatment combinations. With CT and BCT, there was a negative response of chickpea yield and WUE to increasing rates of $\mathrm{N}$ applied to the preceding wheat crop. This can be explained by the greater water use by fertilised wheat, leaving less residual soil moisture for the following chickpea crop. This was different in the NT system, where chickpea yield and WUE increased with increasing rates of fertiliser $\mathrm{N}$ applied to wheat. In this case, the positive effects of soil water conservation on chickpea growth were greater than those of increased water use by the fertilised wheat crop.

Wheat and chickpea GMs decreased in the order NT $>$ CT $>$ BCT (Fig. 5). This was true across seasons at any level of fertiliser $\mathrm{N}$ applied to wheat (results not shown). The wheat GM was lower with BCT compared to CT (Fig. 5a) because of revenue losses related to stubble burning after the wheat phase (Table 3). In the NT system, break-even in wheat production was achieved at all $\mathrm{N}$ rates. In both the $\mathrm{CT}$ and BCT systems, the risk of not breaking even in wheat production was $8 \%$ at N50 (Fig. 5). This risk was greater with N0 (50\%) and N100 (25\%) (not shown). In chickpea, GM differences between CT and BCT were marginal because of similar yields in both tillage systems. Break-even in chickpea production was achieved in all tillage systems (Fig. 5).

Soil organic carbon was highest with NT, followed by $\mathrm{CT}$ and was lowest in the BCT system (Table 3). However, 
Fig. 4 Yield and water-use efficiency (WUE) of wheat (W) and chickpea (CP) crops subjected to conventional tillage (CT), no-tillage (NT) and five levels of fertiliser nitrogen applied to wheat at Tel Hadya. The boxes mark the lower and upper quartiles, the solid and dashed lines show the median and mean, respectively, and the whiskers represent the 10th and 90th percentiles. The results for $\mathrm{CT}$ and a fertiliser rate of $50 \mathrm{~kg} \mathrm{~N} / \mathrm{ha}$ represent those of the reference scenario from simulated rotations
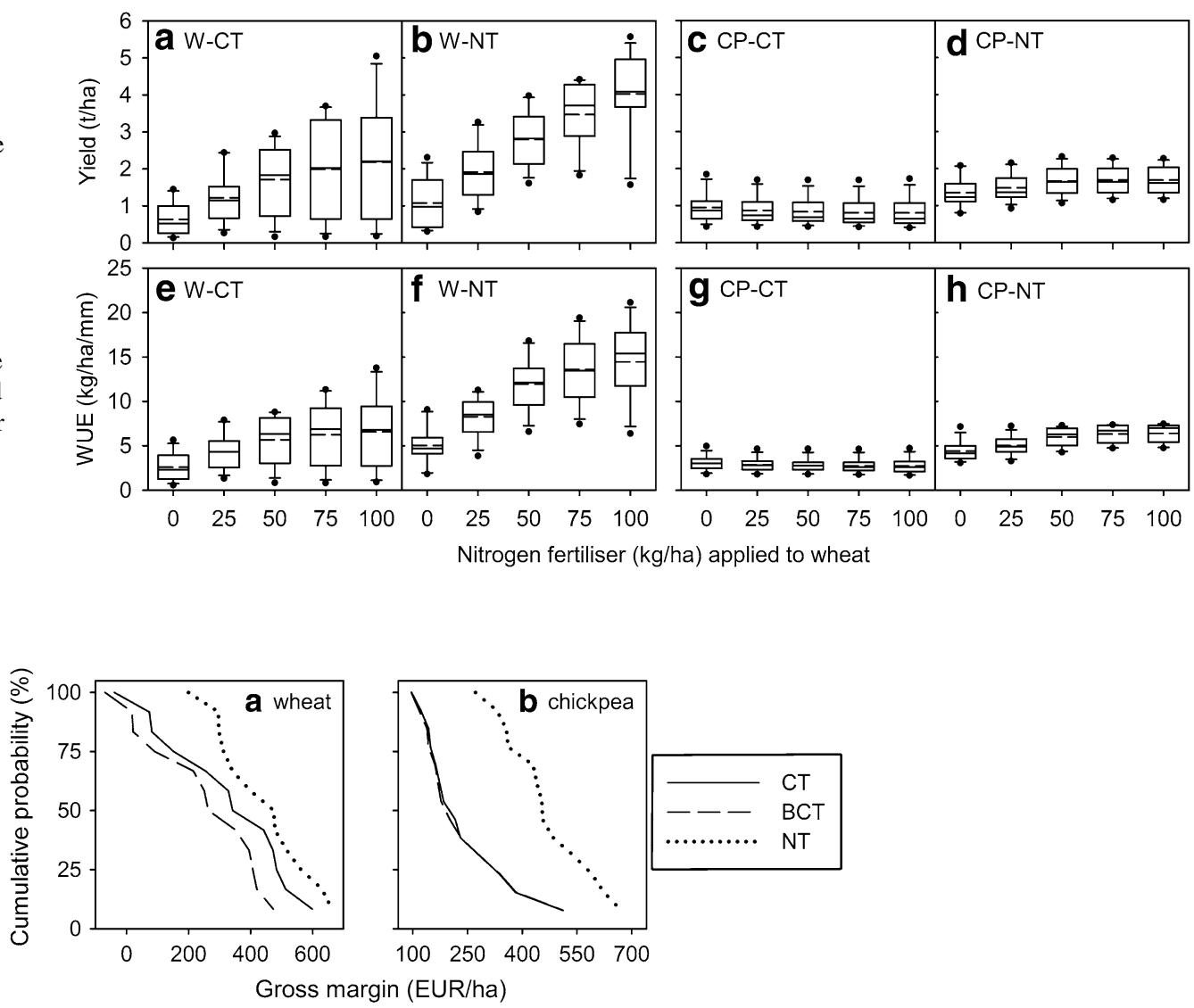

Fig. 5 Cumulative probability of simulated gross margin (GM) for $\mathbf{a}$ wheat and $\mathbf{b}$ chickpea grown in rotations subjected to conventional tillage (CT), conventional tillage with stubble burning after wheat

(BCT) and no-tillage (NT) at Tel Hadya. The fertiliser N applied to wheat was $50 \mathrm{~kg} \mathrm{~N} / \mathrm{ha}$. The solid line represents distributions of GM in the reference scenario

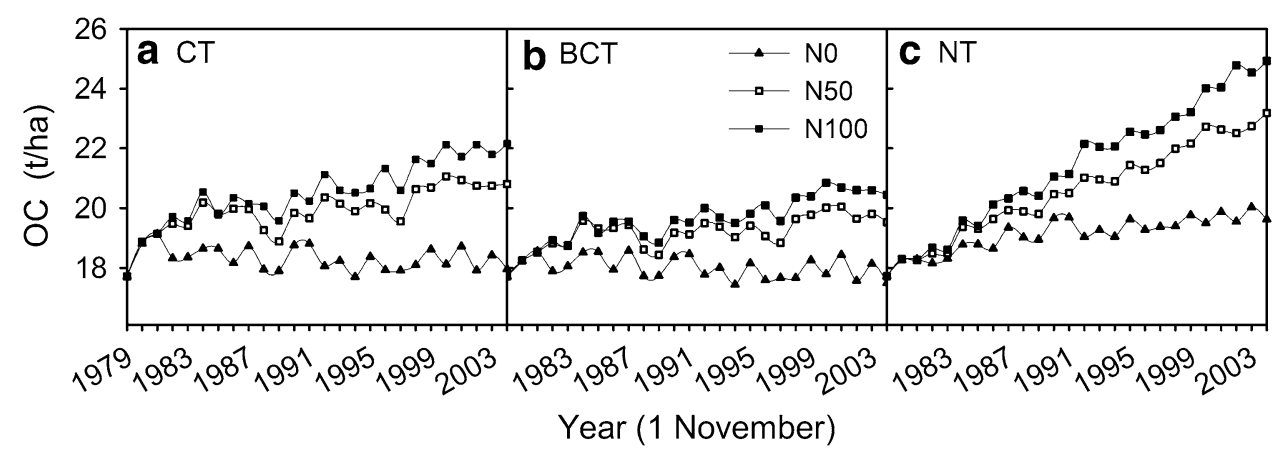

Fig. 6 Soil organic carbon (OC) in $0-0.3-m$ soil depth under a conventional (CT), b burn-conventional (BCT) and c no-tillage (NT) in wheat-chickpea rotations simulated for Tel Hadya. The levels

all management scenarios were sustainable when the initial conditions at the start of the simulations (30 October 1979) were taken as the reference point (Fig. 6), i.e. even when no fertiliser $\mathrm{N}$ was applied. In general, $\mathrm{OC}$ in $0-0.3-\mathrm{m}$ soil depth (as on 1 November) was simulated to increase over 25 seasons with increasing amounts of $\mathrm{N}$ fertiliser and crop residues retained in the system. of fertiliser $\mathrm{N}$ applied to wheat were (filled triangles) 0 , (open squares) 50 and (filled squares) $100 \mathrm{~kg} \mathrm{~N} / \mathrm{ha}$. The results for CT and an $\mathrm{N}$ rate of $50 \mathrm{~kg} \mathrm{~N} / \mathrm{ha}$ represent those of the reference scenario

\section{References}

Abbona EA, Sarandón SJ, Marasas ME, Astier M (2007) Ecological sustainability evaluation of traditional management in different vineyard systems in Berisso, Argentina. Agric Ecosyst Environ 119:335-345

Adams D (1979) The hitchhiker's guide to the galaxy. Pan Books, London 
Agnew C (1995) Environmental change and environmental problems in the Middle East. The Middle Eastern environment. St. Malo Press, Cambridge, pp 21-34

Allenby B, Sarewitz DR (2011) The techno-human condition. MIT Press, Cambridge

Angás P, Lampurlanés J, Cantero-Martínez C (2006) Tillage and N fertilization: effects on $\mathrm{N}$ dynamics and barley yield under semiarid Mediterranean conditions. Soil Tillage Res 87:59-71

Araus JL (2004) The problems of sustainable water use in the Mediterranean and research requirements for agriculture. Ann Appl Biol 144:259-272

Arshad MA, Martin S (2002) Identifying critical limits for soil quality indicators in agro-ecosystems. Agric Ecosyst Environ 88:153-160

Atiya B (2008) Comparative advantages of selected commodities. FAO-Italy Government Cooperation Programme, Project GCP/ SYR/006/ITA. Ministry of Agriculture and Agrarian Reform, National Agricultural Policy Center (NAPC), Damascus, Syria. Available online at: http://www.napcsyr.net/pubs/studies/policy_ studies.htm

Bank A, Becker C (2004) Syrien unter Bashar al-Asad: Strukturen und Herausforderungen. Informationsprojekt Naher und Mittlerer Osten eV (Inamo) 40:4-9. Available online at: http://www. inamo.de/index.php/dossier-syrien.html

Bell S, Morse S (2000) Sustainability indicators: measuring the immeasurable? Earthscan Publications Ltd., London

Benessia A, Funtowicz S, Bradshaw G, Ferri F, Ráez-Luna EF, Medina CP (2012) Hybridizing sustainability: towards a new praxis for the present human predicament. Sustain Sci 7:75-89. doi:10.1007/s11625-011-0150-4

Bergez JE, Colbach N, Crespo O, Garcia F, Jeuffroy MH, Justes E, Loyce C, Munier-Jolain N, Sadok W (2010) Designing crop management systems by simulation. Eur J Agron 32:3-9. doi:10. 1016/j.eja.2009.06.001

Bescansa P, Imaz MJ, Virto I, Enrique A, Hoogmoed WB (2006) Soil water retention as affected by tillage and residue management in semiarid Spain. Soil Tillage Res 87:19-27

Bouma J (2002) Land quality indicators of sustainable land management across scales. Agric Ecosyst Environ 88:129-136

Büchs W (2003) Biotic indicators for biodiversity and sustainable agriculture-introduction and background. Agric Ecosyst Environ 98:1-16

Cantero-Martínez C, Angás P, Lampurlanés J (2003) Growth, yield and water productivity of barley (Hordeum vulgare L.) affected by tillage and $\mathrm{N}$ fertilization in Mediterranean semiarid, rainfed conditions of Spain. Field Crops Res 84:341-357

Carberry PS, Hochman Z, McCown RL, Dalgliesh NP, Foale MA, Poulton PL, Hargreaves JNG, Hargreaves DMG, Cawthray S, Hillcoat N, Robertson MJ (2002) The FARMSCAPE approach to decision support: farmers', advisers', researchers' monitoring, simulation, communication and performance evaluation. Agric Syst 74:141-177

Carrier M (2008) Science and the social. In: Carrier M, Howard D, Kourany J (eds) The challenge of the social and the pressure of practice: science and values revisited. University of Pittsburgh Press, Pittsburgh, pp 1-13

Cassman KG (1999) Ecological intensification of cereal production systems: yield potential, soil quality, and precision agriculture. Proc Natl Acad Sci USA 96:5952-5959

Chaherli N, Hazell P, Ngaido T, Nordblom TL, Oram P (eds) (1999) Agricultural growth, sustainable resource management, and poverty alleviation in the low rainfall areas of West Asia and North Africa. In: Proceedings of the international conference held from 2-6 September 1997, Amman, Jordan. Deutsche Stiftung für Internationale Entwicklung (DSE), Feldafing, Germany, p 283

Clark WC, Tomich TP, van Noordwijk M, Guston D, Catacutan D, Dickson NM, McNie E (2011) Boundary work for sustainable development: natural resource management at the Consultative Group on International Agricultural Research (CGIAR). PNAS. doi:10.1073/pnas.0900231108

Comprehensive Assessment of Water Management in Agriculture (2007) Water for food, water for life: a comprehensive assessment of water management in agriculture. Earthscan, International Water Management Institute, London, Colombo

Cooper PJM, Gregory PJ, Tully D, Harris HC (1987) Improving water use efficiency of annual crops in the rainfed farming systems of West Asia and North Africa. Exp Agric 23:113-158

Cox PG, MacLeod ND, Shulman AD (1997) Putting sustainability into practice in agricultural research for development. In: Stowell FA, Ison RL, Armson R, Holloway J, Jackson S, McRobb S (eds) Systems for sustainability: people, organizations and environments. Plenum Press, New York, pp 33-38

De Vita P, Di Paolo E, Fecondo G, Di Fonzo N, Pisante M (2007) Notillage and conventional tillage effects on durum wheat yield, grain quality and soil moisture content in southern Italy. Soil Tillage Res 92:69-78

D'Emden FH, Llewellyn RS (2006) No-tillage adoption decisions in southern Australian cropping and the role of weed management. Aust J Exp Agric 46:563-569

Dyson T (1999) World food trends and prospects to 2025. Proc Natl Acad Sci USA 96:5929-5936

Erisman JW, Galloway JN, Seitzinger S, Bleeker A, Dise NB, Petrescu AMR, Leach AM, de Vries W (2013) Consequences of human modification of the global nitrogen cycle. Philos Trans Royal Soc B Biol Sci 368:20130116

Fernandez MR, Huber D, Basnyat P, Zentner RP (2008) Impact of agronomic practices on populations of Fusarium and other fungi in cereal and noncereal crop residues on the Canadian Prairies. Soil Tillage Res 100:60-71

Giller KE, Witter E, Corbeels M, Tittonell P (2009) Conservation agriculture and smallholder farming in Africa: the heretics' view. Field Crops Res 114:23-34. doi:10.1016/j.fcr.2009.06.017

Girardin P, Bockstaller C, Van der Werf H (1999) Indicators: tools to evaluate the environmental impacts of farming systems. J Sustain Agric 13:5-21

Gomez AA, Kelly DE, Syers JK, Goughlan KJ (1996) Measuring sustainability of agricultural systems at the farm level. In: Doran JW, Jones AJ (eds) Methods for assessing soil quality SSSA Special Publication No. 49. Soil Science Society of America, Madison

Govaerts B, Sayre KD, Ceballos-Ramirez JM, Luna-Guido ML, Limon-Ortega A, Deckers J, Dendooven L (2006) Conventionally tilled and permanent raised beds with different crop residue management: effects on soil $\mathrm{C}$ and $\mathrm{N}$ dynamics. Plant Soil 280:143-155. doi:10.1007/s11104-005-2854-7

Guston DH (2001) Boundary organizations in environmental policy and science: an introduction. Sci Technol Human Values 26:399-408

Hansen JW (1996) Is agricultural sustainability a useful concept? Agric Syst 50:117-143

Hollander RD (1986) Values and making decisions about agricultural research. Agric Hum Values 3:33-40

Hopfinger H, Boeckler M (1996) Step by step to an open economic system: Syria sets course for liberalization. Br J Middle East Stud 23:183-202

Huff HB (2004) Options for reforming Syrian agricultural policy support instrument in view of WTO accession. FAO-Italy Government Cooperation Programme, Project GCP/SYR/006/ITA. Ministry of Agriculture and Agrarian Reform, National Agricultural Policy Center (NAPC), Damascus, Syria. Available online at: http://www. napcsyr.net/pubs/studies/policy_studies.htm

Jalili S, Fathi G, Fathi Y, Al-Rijabo AS, Piggin C, Desbiolles J (2011) Farmer innovation: seeder fabrication and uptake of zero-tillage 
in Iraq. In: Proceedings of the 5th World Congress on Conservation Agriculture and 3rd Farming Systems Design Conference. WCCA/FSD Local Organising Committee, c/o Australian Centre for International Agricultural Research, Brisbane. Available online at: http://aciar.gov.au/files/node/13993/ farmer_innovation_seeder_fabrication_and_uptake_23210.pdf

Kane M (1999) Sustainability concepts: from theory to practice. In: Köhn J, Gowdy J, Hinterberger F, van der Straaten J (eds) Sustainability in question. Edward Elgar Publishing Ltd., Cheltenham

Kassam SN, Lalani B, Al-Eter B (2011) Conservation agriculture: perspectives from Salamieh district, Syria. In: Proceedings of the 5th World Congress on Conservation Agriculture and 3rd International Farming Systems Design Conference. WCCA/ FSD Local Organising Committee, c/o Australian Centre for International Agricultural Research, Brisbane. Available online at: http://aciar.gov.au/files/node/13994/ca_syria_kassam_pdf_ 19882.pdf

Kassam A, Friedrich T, Derpsch R, Lahmar R, Mrabet R, Basch G, González-Sánchez EJ, Serraj R (2012) Conservation agriculture in the dry Mediterranean climate. Field Crops Res 132:7-17. doi:10.1016/j.fcr.2012.02.023

Keating BA, Carberry PS, Hammer GL, Probert ME, Robertson MJ, Holzworth D, Huth NI, Hargreaves JNG, Meinke H, Hochman Z, McLean G, Verburg K, Snow V, Dimes JP, Silburn M, Wang E, Brown S, Bristow KL, Asseng S, Chapman S, McCown RL, Freebairn DM, Smith CJ (2003) An overview of APSIM, a model designed for farming systems simulation. Eur J Agron 18:267-288

Keating BA, Carberry PS, Bindraban PS, Asseng S, Meinke H, Dixon J (2010) Eco-efficient agriculture: concepts, challenges, and opportunities. Crop Sci 50:S109-S119. doi:10.2135/cropsci2009.10.0594

Knowler D, Bradshaw B (2007) Farmers' adoption of conservation agriculture: a review and synthesis of recent research. Food Policy 32:25-48

Kokic P, Nelson R, Meinke H, Potgieter A, Carter J (2007) From rainfall to farm incomes - transforming advice for Australian drought policy. I. Development and testing of a bioeconomic modelling system. Aust J Agric Res 58:993-1003. doi:10.1071/ar06193

Kropff MJ, Bouma J, Jones JW (2001) Systems approaches for the design of sustainable agro-ecosystems. Agric Syst 70:369-393

Kuratorium für Technik und Bauwesen in der Landwirtschaft (2009) Kalkulationsdaten, Pflanzenproduktion. Kuratorium für Technik und Bauwesen in der Landwirtschaft eV (KTBL) Darmstadt. http://www.ktbl.de

Lal R (2000) Soil management in the developing countries. Soil Sci 165:57-72

Lal R (2002) Carbon sequestration in dryland ecosystems of West Asia and North Africa. Land Degrad Dev 13:45-59

Lampurlanés J, Angás P, Cantero-Martínez C (2002) Tillage effects on water storage during fallow, and on barley root growth and yield in two contrasting soils of the semi-arid Segarra region in Spain. Soil Tillage Res 65:207-220

Leenders R, Heydemann S (2012) Popular mobilization in Syria: opportunity and threat, and the social networks of the early risers. Mediterr Politics 17:139-159. doi:10.1080/13629395. 2012.694041

López-Bellido L (1992) Mediterranean cropping systems. In: Pearson CJ (ed) Field crop ecosystems. Elsevier, Amsterdam

Luo Z, Wang E, Sun OJ, Smith CJ, Probert ME (2011) Modeling long-term soil carbon dynamics and sequestration potential in semi-arid agro-ecosystems. Agric For Meteorol 151: $1529-1544$

McCown RL (2001) Learning to bridge the gap between sciencebased decision support and the practice of farming: evolution in paradigms of model-based research and intervention from design to dialogue. Aust J Agric Res 52:549-571
McCown RL (2002) Changing systems for supporting farmers' decisions: problems, paradigms, and prospects. Agric Syst 74:179-220

Meinke H, Hammer GL, van Keulen H, Rabbinge R, Keating BA (1997) Improving wheat simulation capabilities in Australia from a cropping systems perspective: water and nitrogen effects on spring wheat in a semi-arid environment. Eur J Agron 7:75-88

Meinke H, Baethgen W, Carberry PS, Donatelli M, Hammer GL, Selvaraju R, Stöckle CO (2001) Increasing profits and reducing risks in crop production using participatory systems simulation approaches. Agric Syst 70:493-513

Meinke H, Howden SM, Struik PC, Nelson R, Rodriguez D, Chapman SC (2009) Adaptation science for agriculture and natural resource management-urgency and theoretical basis. Curr Opin Environ Sustain 1:69-76. doi:10.1016/j.cosust.2009.07.007

Meyer R (2011) The public values failures of climate science in the US. Minerva 49:47-70. doi:10.1007/s11024-011-9164-4

Meyer JR, Campbell CL, Moser TJ, Hess GR, Rawlings JO, Peck S, Heck WW (1992) Indicators of the ecological status of agroecosystems. In: McKenzie DE, Hyatt DE, McDonald VJ (eds) Ecological indicators. Elsevier, Amsterdam, pp 629-658

Ministry of Agriculture and Agrarian Reform (1999) Agricultural statistics in 1997. Directorate of Planning and Statistics, Division of Agricultural Statistics, Damascus, Syria

Ministry of Agriculture and Agrarian Reform (2000) The annual agricultural abstract. Directorate of Planning and Statistics, Division of Agricultural Statistics, Damascus, Syria

Moeller C, Pala M, Manschadi AM, Meinke H, Sauerborn J (2007) Assessing the sustainability of wheat-based cropping systems using APSIM: model parameterisation and evaluation. Aust $\mathrm{J}$ Agric Res 58:75-86

Moeller C, Smith I, Asseng S, Ludwig F, Telcik N (2008) The potential value of seasonal forecasts of rainfall categories-case studies from the wheatbelt in Western Australia's Mediterranean region. Agric For Meteorol 148:606-618. doi:10.1016/j. agrformet.2007.11.004

Moeller C, Asseng S, Berger J, Milroy SP (2009) Plant available soil water at sowing in Mediterranean environments-is it a useful criterion to aid nitrogen fertiliser and sowing decisions? Field Crops Res 114:127-136. doi:10.1016/j.fcr.2009.07.012

Mohanty M, Probert ME, Reddy KS, Dalal RC, Mishra AK, Rao AS, Singh M, Menzies NW (2012) Simulating soybean-wheat cropping system: APSIM model parameterization and validation. Agric Ecosyst Environ 152:68-78

Möller C (2004) Sustainable management of a wheat-chickpea rotation in a Mediterranean environment: scenario analyses using a cropping systems simulator. Agroecology 6. APIA, Laubach, Germany

Monteith JL (1996) The quest for balance in crop modeling. Agron J 88:695-697

Mrabet R, Saber N, El-Brahli A, Lahlou S, Bessam F (2001) Total, particulate organic matter and structural stability of a Calcixeroll soil under different wheat rotations and tillage systems in a semiarid area of Morocco. Soil Tillage Res 57:225-235

Muchow RC, Keating BA (1998) Assessing irrigation requirements in the Ord Sugar Industry using a simulation modelling approach. Aust J Exp Agric 38:345-354

Murray-Prior RB, Whish J, Carberry P, Dalgliesh N (2005) Lucerne improves some sustainability indicators but may decrease profitability of cropping rotations on the Jimbour Plain. Aust J Exp Agric 45:651-663

Nelson R, Kokic P, Meinke H (2007) From rainfall to farm incomestransforming advice for Australian drought policy. II. Forecasting farm incomes. Aust J Agric Res 58:1004-1012. doi:10.1071/ ar06195

Nelson R, Kokic P, Crimp S, Meinke H, Howden SM (2010a) The vulnerability of Australian rural communities to climate 
variability and change: Part I-conceptualising and measuring vulnerability. Environ Sci Policy 13:8-17. doi:10.1016/j.envsci. 2009.09.006

Nelson R, Kokic P, Crimp S, Martin P, Meinke H, Howden SM, de Voil P, Nidumolu U (2010b) The vulnerability of Australian rural communities to climate variability and change: Part IIintegrating impacts with adaptive capacity. Environ Sci Policy 13:18-27. doi:10.1016/j.envsci.2009.09.007

Nortcliff S (2002) Standardisation of soil quality attributes. Agric Ecosyst Environ 88:161-168

OANDA (2009) Currency converter. OANDA Corporation, New York. Available online at: http://www.oanda.com/currency/ converter/

O'Connor T, Wong HY (2012) Emergent Properties. In: Zalta EN (ed) The Stanford encyclopedia of philosophy. Spring 2012 Edition. Available online at: http://plato.stanford.edu/archives/ spr2012/entries/properties-emergent/

Pala M, Rodríguez A (1993) Wheat monitoring study in farmer's fields of northwest Syria. Farm resource management program: annual report for 1992. ICARDA, Aleppo, Syria, pp 121-138

Pala M, van Duivenbooden N, Studer C, Bielders CL (1999) Cropping systems and crop complementarity in dryland agriculture. In: van Duivenbooden N, Pala M, Studer C, Bielders CL (eds) Efficient soil water use: the key to sustainable crop production in the dry areas of West Asia, and North and SubSaharan Africa. ICARDA, Aleppo, Syria; ICRISAT, Patancheru, India, pp 299-330

Pala M, Harris HC, Ryan J, Makboul R, Dozom S (2000) Tillage systems and stubble management in a Mediterranean-type environment in relation to crop yield and soil moisture. Exp Agric 36:223-242

Pala M, Ryan J, Zhang H, Singh M, Harris HC (2007) Water-use efficiency of wheat-based rotation systems in a Mediterranean environment. Agric Water Manag 93:136-144

Pape-Christiansen A (2001) Intensification of rainfed agriculture in Northern Syria: implications of perennial crops and irrigation on farm-household development. Wissenschaftsverlag Vauk, Kiel

Passioura JB, Angus JF (2010) Improving productivity of crops in water-limited environments. Adv Agron 106:37-75

Peck SL (2004) Simulation as experiment: a philosophical reassessment for biological modeling. Trends Ecol Evol 19:530-534. doi:10.1016/j.tree.2004.07.019

Perrier ER, Salkini AB, Ward CF (eds) (1991) Supplemental irrigation in the Near East and North Africa. Kluwer Academic Publishers, Dordrecht

Probert ME, Carberry PS, McCown RL, Turpin JE (1998a) Simulation of legume-cereal systems using APSIM. Aust J Agric Res 49:317-327

Probert ME, Dimes JP, Keating BA, Dalal RC, Strong WM (1998b) APSIM's water and nitrogen modules and simulation of the dynamics of water and nitrogen in fallow systems. Agric Syst 56:1-28

Rijsberman F, Mohammed A (2003) Water, food and environment: conflict or dialogue? Water Sci Technol 47:53-62

Riley J (2001) The indicator explosion: local needs and international challenges. Agric Ecosyst Environ 87:119-120

Robertson MJ, Carberry PS, Huth NI, Turpin JE, Probert ME, Poulton PL, Bell M, Wright GC, Yeates SJ, Brinsmead RB (2002) Simulation of growth and development of diverse legume species in APSIM. Aust J Agric Res 53:429-446

Rodríguez A (1995) Challenges for the agricultural sector in developing Mediterranean countries. ICARDA, Aleppo

Rodríguez A, Thomas N (1998) Mapping rural poverty and natural resource constraints in dry areas. ICARDA, Aleppo

Rodríguez A, Salahieh H, Badwan R, Khawam H (1999) Groundwater use and supplemental irrigation in Atareb, Northwest Syria. ICARDA, Aleppo
Roldan A, Salinas-Garcia JR, Alguacil MM, Caravaca F (2007) Soil sustainability indicators following conservation tillage practices under subtropical maize and bean crops. Soil Tillage Res 93:273-282. doi:10.1016/j.still.2006.05.001

Roozitalab MH (2000) Collaboration in agricultural research and technology development: a key to regional food security and sustainable agricultural development in WANA region. GFAR2000, May 21-23. Global Forum on Agriculture Research, Rome, Dresden. Available online at: http://www.fao.org/docs/ eims/upload/206825/GFAR23.PDF

Ruttan VW (1999) The transition to agricultural sustainability. Proc Natl Acad Sci USA 96:5960-5967

Ryan J, Pala M, Masri S, Singh M, Harris H (2008) Rainfed wheatbased rotations under Mediterranean conditions: crop sequences, nitrogen fertilization, and stubble grazing in relation to grain and straw quality. Eur J Agron 28:112-118

Seale P (2013) Time for a settlement in Syria. Agence Global. Available online at: http://www.agenceglobal.com/index. php?show $=$ article $\&$ Tid $=3017$

Smith OH, Petersen GW, Needelman BA (2000) Environmental indicators of agroecosystems. Adv Agron 69:75-97

ten Brink BJE, Hosper SH, Colijn F (1991) A quantitative method for description and assessment of ecosystems: the AMOEBAapproach. Mar Pollut Bull 23:265-270

Thomas GA, Titmarsh GW, Freebairn DM, Radford BJ (2007) Notillage and conservation farming practices in grain growing areas of Queensland-a review of 40 years of development. Aust J Exp Agric 47:887-898

Thompson PB (1992) The varieties of sustainability. Agric Hum Values 9:11-19

Tutwiler R, Termanini A, Bahhady F (1990) Stubble burning in northwest Syria, 1988: an interim report. Farm Resource Management Program Annual Report for 1989. ICARDA, Aleppo

Tutwiler R, Haddad N, Thomson EF (1997) Crop-livestock integration in the drier areas of west Asia and north Africa. In: Haddad $\mathrm{N}$, Tutwiler R, Thomson EF (eds) Improvement of croplivestock integration systems in west Asia and north Africa. Proceedings of the Regional Symposium, 6-8 November, 1995, Amman, Jordan. ICARDA, Aleppo, pp 5-22

Varela-Ortega C, Sagardoy JA (2002) Analysis of irrigation water policies in Syria: current developments and future options. In: Proceedings of the International conference on irrigation water policies: micro and macro considerations, Agadir, Morocco 15-17 June, 2002. The World Bank, Washington DC

Verhulst N, Carrillo-García A, Moeller C, Trethowan R, Sayre KD, Govaerts B (2011) Conservation agriculture for wheat-based cropping systems under gravity irrigation: increasing resilience through improved soil quality. Plant Soil 340:467-479. doi:10. 1007/s11104-010-0620-y

Virto I, Imaz MJ, Enrique A, Hoogmoed W, Bescansa P (2007) Burning crop residues under no-till in semi-arid land, Northern Spain - effects on soil organic matter, aggregation, and earthworm populations. Aust J Soil Res 45:414-421

von Wirén-Lehr S (2001) Sustainability in agriculture-an evaluation of principal goal-oriented concepts to close the gap between theory and practice. Agric Ecosyst Environ 84:115-129

Walker WE, Marchau VAWJ (2003) Dealing with uncertainty in policy analysis and policymaking. Integr Assess 4:1-4

Wehrheim P (2003) Agricultural and food policies in Syria: financial transfers and fiscal flows. In: Fiorillo C, Vercueil J (eds) Syrian agriculture at the crossroads. FAO, Rome, pp 87-114. Available online at: http://www.fao.org/docrep/006/y4890e/y4890e0c.htm\#bm12

Whitbread AM, Robertson MJ, Carberry PS, Dimes JP (2010) How farming systems simulation can aid the development of more sustainable smallholder farming systems in southern Africa. Eur J Agron 32:51-58. doi:10.1016/j.eja.2009.05.004 